scientific officer, plant breeder, West African Cacao Research Institute, Gold Coast; D. Dow, assistant cacao propagation officer, Jamaica; M. Sanders and B. M. Savory, assistant conservators of forests, Northern Rhodesia ; A. E. Wright, geologist, Tanganyika ; D. G. Godfrey, scientific officer (parasitologist), West African Institute for Trypanosomiasis Research, Nigeria; N. A. Hancock, veterinary parasitologist, Northern Region, Nigeria; R. M. Mackenzie, veterinary officer, Eastern Region, Nigeria; B. A. V. Peacock, curator of museums, Federation of Malaya.

Plastic Theory of Engineering Structures: Symposium in Cambridge

A symposium on "The Plastic Theory of Structures" will be held in the Engineering Department of the University of Cambridge during September 18-21. For twenty years a research team under the direction of Prof. J. F. Baker has been at work, at first in Bristol and since 1943 in Cambridge, investigating the behaviour of steel structures in the plastic range and developing a plastic method of designing structures. The stage has now been reached where a new branch of the theory of structures of considerable educational value is available together with a practical method of design of wide application. The symposium is therefore designed to bring together those who teach engineering and those who are practising members of the profession. The fee for the symposium is ten guineas, which will cover all living expenses, a preliminary set of the papers, and a final set of reprints, including the discussions. Further information can be obtained from the Secretary of the Department of Engineering, Trumpington Street, Cambridge.

\section{Dilogarithms and Related Functions}

Mr. L. LewiN, 33 Wellington Road, Enfield, Middlesex, writes : "I am in the course of preparing the manuscript for a book on dilogarithms and related functions and would appreciate the opportunity to appeal to readers who have encountered these functions in the course of their work. Any information on their occurrence in practical problems, and which I could incorporate, with due acknowledgment, would be welcome. The functions concerned arise from the series $\sum_{1}^{\infty} x^{n} / n^{r}$ and the integral $\int \log ^{n}(x) \mathrm{d} x /(1+x)$, and include the log sine integral".

\section{The Night Sky in July}

NEw moon occurs on July 8d. 04h. 37m., U.T., and full moon on July $22 \mathrm{~d}$. $21 \mathrm{~h}$. $29 \mathrm{~m}$. The following conjunctions with the Moon take place: July 6d. 17h., Venus $3^{\circ}$ S.; July 7d. 05h., Mercury $2^{\circ}$ N. ; July 11 d. 07h., Jupiter $7^{\circ}$ N. ; July 17d. 15h., Saturn $11^{\circ}$ N. ; July $27 \mathrm{~d}$. $14 \mathrm{~h}$., Mars $11^{\circ} \mathrm{S}$. In addition to these conjunctions with the Moon, Jupiter is in conjunction with Regulus on July 2d. 09h., Jupiter being $0.6^{\circ} \mathrm{N}$., and Mercury is in conjunction with Regulus on July 3d. 20h., Mercury $3 \cdot 3^{\circ}$ N. ; also, on July 3d. 20h., Mercury is in conjunction with Venus, Mercury $3 \cdot 3^{\circ} \mathrm{N}$. Mercury rises at $2 \mathrm{~h}$. $40 \mathrm{~m}$., $3 \mathrm{~h} .30 \mathrm{~m}$. and $4 \mathrm{~h} .45 \mathrm{~m}$. on July 1,15 and 31 , respectively, but is too close to the Sun for favourable observation. Venus rises at $3 \mathrm{~h} .20 \mathrm{~m} ., 2 \mathrm{~h} .20 \mathrm{~m}$. and lh. $40 \mathrm{~m}$. at the beginning, middle and end of the month, respectively. The close approach of Regulus, Jupiter, Venus and Mercury (though Mercury may be difficult to see) on July 3 should be an interesting phenomenon. Mars rises at $23 \mathrm{~h}$. $20 \mathrm{~m}$., $22 \mathrm{~h}$. $40 \mathrm{~m}$. and $21 \mathrm{~h} .50 \mathrm{~m}$. on July 1,15 and 31 , respectively, and is visible during the later hours of the night and the morning hours before twilight. Its eastward movement in Aquarius is easily detected, though it lies too low for good observation. Jupiter sets at $22 \mathrm{~h}$. $35 \mathrm{~m}$. and $21 \mathrm{~h} .45 \mathrm{~m}$. on July 1 and 15 , respectively, but later in the month is too close to the Sun for favourable observation. Saturn lies low in the constellation Libra and towards the end of the month is a little south of $\gamma$ Librae. It sets at $1 \mathrm{~h}$. 30m., $0 \mathrm{~h}$. $30 \mathrm{~m}$. and $23 \mathrm{~h}$. $30 \mathrm{~m}$. on July 1,15 and 31 , respectively. Occultations of stars brighter than magnitude 6 are limited to $c$ Cap., magnitude $\mathbf{5 \cdot 3}$, which disappears on July 25d. 0h. 05m., observation being made at Greenwich. The Earth is in aphelion on July 5d. 0lh., its distance from the Sun being then $94 \frac{1}{2}$ million miles.

\section{Announcements}

THE University of Minnesota has recently made the Elvin Charles Stakman Award to Prof. W. L. Waterhouse, of the University of Sydney. This award consists of a medal, a scroll and a nominal monetary grant, and has been given for outstanding contributions to the biology of the cereal rusts and to basic concepts useful in the production of diseaseresistant plants.

The title of reader in physical chemistry in the University of London has been conferred on Dr. J. A. Kitchener, and that of reader in acoustics in the University of London on Dr. R. W. B. Stephens, both being in respect of posts held at the Imperial College of Science and Technology.

THE following awards have been made by the Lady Tata Memorial Fund for research on leukæmia and allied diseases during the academic year 195657: Grants for Research Expenses, Dr. Morten Simensen (Fibiger Laboratories, Copenhagen) and Prof. B. Thorell (Caroline Institute, Stockholm); Scholarships (whole-time or part-time), Dr. Giuseppe Marinone (University Medical Clinic, Pavia) and Dr. A. J. Therkelsen (Institute for General Pathology, University of Aarhus). Various awards made to the following in previous years (see Nature, 175, 1067 ; 1955) have been renewed for a further year: Dr. J. Kieler, Dr. J. Ringsted and Dr. J. Rygaard (Copenhagen); Dr. J. Nordmann (Paris); Dr. A. Sreenivasan (Bombay); Prof. H. G. Teir (Helsinki); Dr. C. G. V. Wasastjerna (Vasa, Finland); Dr. M. Seligmann (Paris); and Dr. Alice Stewart (Oxford).

THe seventh Canadian High Polymer Forum will be held at the Guildwood Inn, Sarnia, Ontario (postal address: P.O. Box 912, Point Edward, Ont.), during November 8-9. The Forum is sponsored by the National Research Council of Canada and by the Chemical Institute of Canada and is devoted to all aspects of polymer science. The guest speaker will be Prof. J. J. Hermans, of the University of Leyden. Abstracts and titles of papers should be sent by August 31 to the programme chairman, Dr. D. G. Ivey, Department of Physics, University of Toronto, Toronto 5, Ontario. All other communications regarding the Forum should be addressed to the chairman, Dr. H. Leverne Williams, Polymer Corporation, Ltd., Sarnia, Ontario.

Erratum. In a communication entitled "Muscular Dystrophy of Beef Cattle and Unsaturated Fats" in Nature of April 28, p. 792, the heading for col. 3 of Table 1 should read "Mean tocopherol content of milk fat ( $\mu \mathrm{gm} . / \mathrm{gm}$.$) ".$ 